\title{
Effectiveness of different removal methods of artificially demineralized dentin
}

\section{Efetividade de diferentes métodos de remoção de dentina desmineralizada artificialmente}

\author{
Camila Ferraz ${ }^{1}$, Patrícia Lima Thé1, Juliano Sartori Mendonça², Carlos Augusto Fernandes², Lidiany Karla
} Azevedo Rodrigues ${ }^{2}$, Monica Yamauti ${ }^{1}$.

\begin{abstract}
Objective: This study aimed to evaluate the effectiveness of different mechanical methods for the removal of demineralized dentin. Methods: Healthy human third molars were prepared in such a way that the flat occlusal surfaces of the dentin were exposed and longitudinally sectioned in a vestibular-lingual direction. One section of each tooth was submitted to the $\mathrm{pH}$-cycling model, while the other section was kept intact. The tooth sections were joined, and a single operator performed dentin removal using a steel bur, a hand instrument, or a polymer bur. The tooth's sections were then separated, and digital images were obtained. The depth of the prepared cavities and the microhardness measurements were checked and analyzed statistically using the Kruskal-Wallis One-Way ANOVA in Ranks, the Tukey test, while desmineralized dentin were compared using the One-Way ANOVA, and the Holm-Sidak method $(\mathrm{p}<0.05)$. Results: The steel bur produced the deepest cavities in mineralized and demineralized dentin. The polymer bur generated the shallowest cavities in demineralized dentin. The measurements of microhardness of the deepest surfaces of the cavities prepared in demineralized dentin indicated that the steel bur and hand instrument presented similar values, while those values produced by polymer burs proved to be lower. Conclusion: The effectiveness of the removal of demineralized dentin varied among the three methods used in this study. The polymer bur proved to be the most conservative of the methods used. By contrast, the steel bur and hand instrument showed a similar effectiveness in the removal of dentin, according to the microhardness of the remaining dentin, even though they produced different cavity depths.
\end{abstract}

Uniterms: Tooth demineralization. Dental cavity preparation. Hardness tests.

\section{INTRODUCTION}

Caries is a dynamic process of demineralization and remineralization that can lead to lesion formation in enamel and dentin. Fusayama, Okuse, Hosoda $(1966)^{1}$ described two layers of carious dentin: (1) the outer carious dentin (or caries-infected dentin), which is contaminated with bacteria and in which the collagen fibers are degraded and cannot be remineralized; and (2) the inner carious dentin (socalled caries-affected dentin), which is bacteria-free with limited denaturation of the collagen and which can be remineralized.

The conventional dentistry approach to caries treatment has been surgery, removing diseased tissue and replacing it with a dental restorative material. This approach was deemed necessary given our team's understanding of the disease process and the limitations of available materials ${ }^{2}$. Mechanical caries removal traditionally involves the use of conventional tungsten carbide or round steel burs and hand instrument. These are called conventional methods, which have some disadvantages, such as the overpreparation of cavities, pain sensitivity during the caries removal of surrounding sound tissue, and possible damage to pulp tissue, due to elevated temperature and pressure on the pulp ${ }^{3}$. Nevertheless, the exact endpoint of caries removal is not clinically easy to define ${ }^{4}$.

The current concept of minimally-invasive dentistry endorses selective caries removal, where caries should be selectively removed to preserve as much sound or caries-affected dentin as possible ${ }^{5}$. However, this goal is not easily achieved in clinical practice. The search for a more gentle, comfortable, and conservative caries excavation has led to the development of methods which aim to provide minimal thermal change, less vibration and pain, and the removal of infected dentin only. Recently, a novel,

\footnotetext{
${ }^{1}$ School of Dentistry, College of Pharmacy, Dentistry and Nursing, Universidade Federal do Ceará, Fortaleza, Ceará, Brazil. ${ }^{2}$ Department of Restorative Dentistry, College of Pharmacy, Dentistry and Nursing, Universidade Federal do Ceará, Fortaleza, Ceará, Brazil. Contatos: camilaferraz14@hotmail.com, patricialimathe@yahoo.com.br, mendoncajs@hotmail.com, carlosfernandesufc@gmail.com,

lidianykarla@yahoo.com,myamauti@gmail.com
} 
self-limiting concept in mechanical caries removal, the polymer bur, was developed with a particular hardness and wear resistance that reportedly enable it to remove only the soft caries-infected dentin, leaving the caries-affected dentin intact ${ }^{6-7}$. Polymer burs have been developed to safely remove carious dentin in an attempt to overcome the drawbacks of conventional caries removal methods ${ }^{6-7}$. Patients have reported a preference for the polymer bur rather than the carbide bur $^{8}$. However, the efficacy of these new burs on selectively and efficiently removing caries is not well established.

A study model is important to simulate the process of caries, and although there has been progress of in situ and in vivo research in Cariology, laboratory tests are still widely used to evaluate dental caries ${ }^{9-11}$. Among these models, those mimicking in vitro caries processes ( $\mathrm{pH}$-cycling) ${ }^{11}$, are important to reproduce the dynamics of mineral loss and gain involved in caries formation ${ }^{12}$.

Therefore, the aim of the present study is to investigate the effectiveness of three methods of dentin excavation used to remove artificially demineralized dentin. The null hypotheses tested were the following: (1) there will be no difference in the cavity depths produced on mineralized and demineralized dentin when using different excavation methods; and (2) there will be no difference in the microhardness of the remaining mineralized and demineralized dentin after the use of different dentin excavation methods.

\section{METHODS}

The Research Ethics Committee of the Institution approved the study (Protocol $\mathrm{n}^{\mathrm{o}}$. 107/12). Extracted human third molars were obtained with informed consent from the donors.

Thirty sound third molars were stored in a $0.1 \%$ thymol $(\mathrm{w} / \mathrm{v})$ solution at $4^{\circ} \mathrm{C}$ and used within three months. The teeth were transversely sectioned below the dentin-enamel junction with a low-speed diamond saw at a thickness of $300 \mu \mathrm{m}$ (IsoMet ${ }^{\mathrm{TM}}$ Low Speed Saw, Buehler, Lake Bluff, IL, USA). They were then ground flat (600-grit) under running water to provide standardized smear-layer covered dentin surfaces. All specimens were analyzed using a stereomicroscope (Leica Microsystems, Wetzlar, Deutschland, Germany) at $10 \mathrm{X}$ magnification to ensure complete removal of the enamel. The teeth were then bisected longitudinally in a buccal-lingual direction. In one of the hemi-sections, all of the surfaces, except for an area of $16 \mathrm{~mm}^{2}$, were protected with an acid-resistant varnish (Colorama, São Paulo, Brazil).

The hemi-sections that were not varnishprotected were stored in $100 \%$ humidity at $4^{\circ} \mathrm{C}$. These corresponded to the mineralized dentin groups.
The remaining hemi-sections were submitted to a $\mathrm{pH}$-cycling regimen at $37^{\circ} \mathrm{C}$, corresponding to the demineralized dentin groups. A modified $\mathrm{pH}$-cycling model was used to simulate the cariogenic challenge and to create artificial dentin carious lesions ${ }^{9,11}$. The demineralizing solution contained $2 \mathrm{mM} \mathrm{Ca}, 0.075 \mathrm{M}$ acetic acid, and $2 \mathrm{mM} \mathrm{PO}_{4}$, with the $\mathrm{pH}$ adjusted to 4.35 with $\mathrm{HCl}$. The remineralizing solution contained $1.5 \mathrm{mM} \mathrm{Ca}, 0.9 \mathrm{mM} \mathrm{PO}_{\overline{4}}^{-}, 0.15 \mathrm{mM} \mathrm{KCl}$, and $0.1 \mathrm{M}$ Tris buffer adjusted to a $\mathrm{pH}$ of 7.42. Each sample was individually immersed in $30 \mathrm{~mL}$ of demineralizing solution for four hours, washed in distilled water, dried with paper towels, and individually immersed in $15 \mathrm{~mL}$ of remineralizing solution for 20 hours. This procedure was carried out at $37^{\circ} \mathrm{C}$, completing a cycle of 24 hours. These cycles were performed for eight consecutive days. On the fourth day of the cycle, the solutions were replaced. After the eighth day of the cycle, the samples were put in fresh remineralizing solution for 24 hours $^{13}$.

The hemi-sections of each tooth were reassembled for caries removal using cyanoacrylate adhesive applied to the external surface of the crown, matching both parts. The operator was selected because of his broad clinical experience as well as the previous training and calibration sessions that he attended in order to use the three caries removal methods. The same operator prepared the dentin cavities according to the previous criteria, and then excavated ten teeth in each group as follows:

- Group 1: Conventional round steel bur. Brand new \#6 and \#8 round burs (Dentsply Maillefer, Ballaigues, Switzerland) were used in a slow-speed handpiece. Demineralized dentin excavation was stopped when hard dentin was detected using a nonflexible probe. Dentin was considered hard when, at applying a firm pressure, the probe was not able to penetrate into tissue ${ }^{14}$. Demineralized dentin was removed with circular movements, starting from the periphery to the center of the artificial lesion ${ }^{14}$. A new bur was used for each tooth.

- Group 2: Hand instrument. Demineralized dentin was removed using either $\# 14$ or $\# 19$ excavators (SS White Duflex, Rio de Janeiro, Brazil). New excavators were used for each caries lesion. During excavation, dentin hardness was checked and demineralized dentin removal was completed when hard tissue was detected using a non-flexible probe.

- Group 3: Polymer bur. New \#6 and \#8 SmartBurs ${ }^{\circledR} 2$ (SS White, Lakewood, NJ, USA) were used with a slow-speed handpiece. Demineralized dentin tissue was removed with circular movements, starting from the center of the lesion to the periphery, as recommended by the manufacturer. Excavation was stopped when the instrument became macroscopically abraded and blunted, and was no longer able to remove 
tissue ${ }^{6}$. New polymer burs were used for each tooth.

In the case of the mineralized dentin halves of each group, tactile judgment was employed to evaluate the consistency of the dentin tissue through the use of a non-flexible probe.

The hemi-sections of all the teeth were embedded in acrylic resin (JET, Campo Limpo Paulista, SP, Brazil) so that the area to be analyzed remained exposed. Samples were polished with a rotary polisher (Universal polishing Aropol 2VR, Arotec, Cotia, São Paulo, Brazil) using \#600, \#800, $\# 1200$, and \#4000 grit SiC papers, and with $1 \mu \mathrm{m}$ diamond paste under water irrigation (Arotec, Cotia, São Paulo, Brazil). All samples were ultrasonically cleaned (Ultra-Cleaner 1400, São Paulo, Brazil) for $10 \mathrm{~min}$ to remove residues and impurities. The polishing was considered ideal when the samples' surfaces were smooth and shiny, with no visible irregularities when viewed under a stereoscope (Leica Microsystems, Wetzlar, Deutschland, Germany) at $60 \mathrm{X}$ magnification. Specimens were placed over a dark and opaque surface and digital images were taken using a Digital Single Lens Reflex (DSLR) commercial camera (D70, Nikon Inc., Melville, NY, USA) with a Medical Nikkor lens (Nikkor,
Tokyo, Japan) operating in manual mode with fixed parameters. The obtained images were analyzed using MacBiophotonics ImageJ (Wayne Rashband, National Institutes of Health, USA) to measure the cavity depth after the dentin excavation with each method on mineralized and demineralized dentin. Measurements were performed from the dentin occlusal surface to the deepest portion of the cavity. Data on cavity depths were registered in $\mu \mathrm{m}$ and tabulated.

Microhardness measurements were performed on mineralized and demineralized hemi-sections (Figure 1). For this measurement, a microhardness tester (Future-Tech FM Future-Tech Corporation, Kawasaki, Kanagawa, Japan) was used with a Knoop indenter using a $10 \mathrm{~g}$ static load applied for $10 \mathrm{sec}^{15}$. Thirty-six indentations were made, divided into three columns that were $100 \mu \mathrm{m}$ apart at depths of 10 , $20,30,40,50,60,80,100,120,140,180$, and 200 $\mu \mathrm{m}$ from the bottom of the cavity floor towards the pulp9. For each specimen at each dentin level from the pulp floor, a value was obtained by calculating the mean between the three measurements. Data on microhardness were registered in $\mathrm{kgf} / \mathrm{mm}^{2}$. The real level of each indentation was considered the sum of pre-defined indentation level and cavity depth.

Figure 1 - Schematic representation of microhardness measurement.

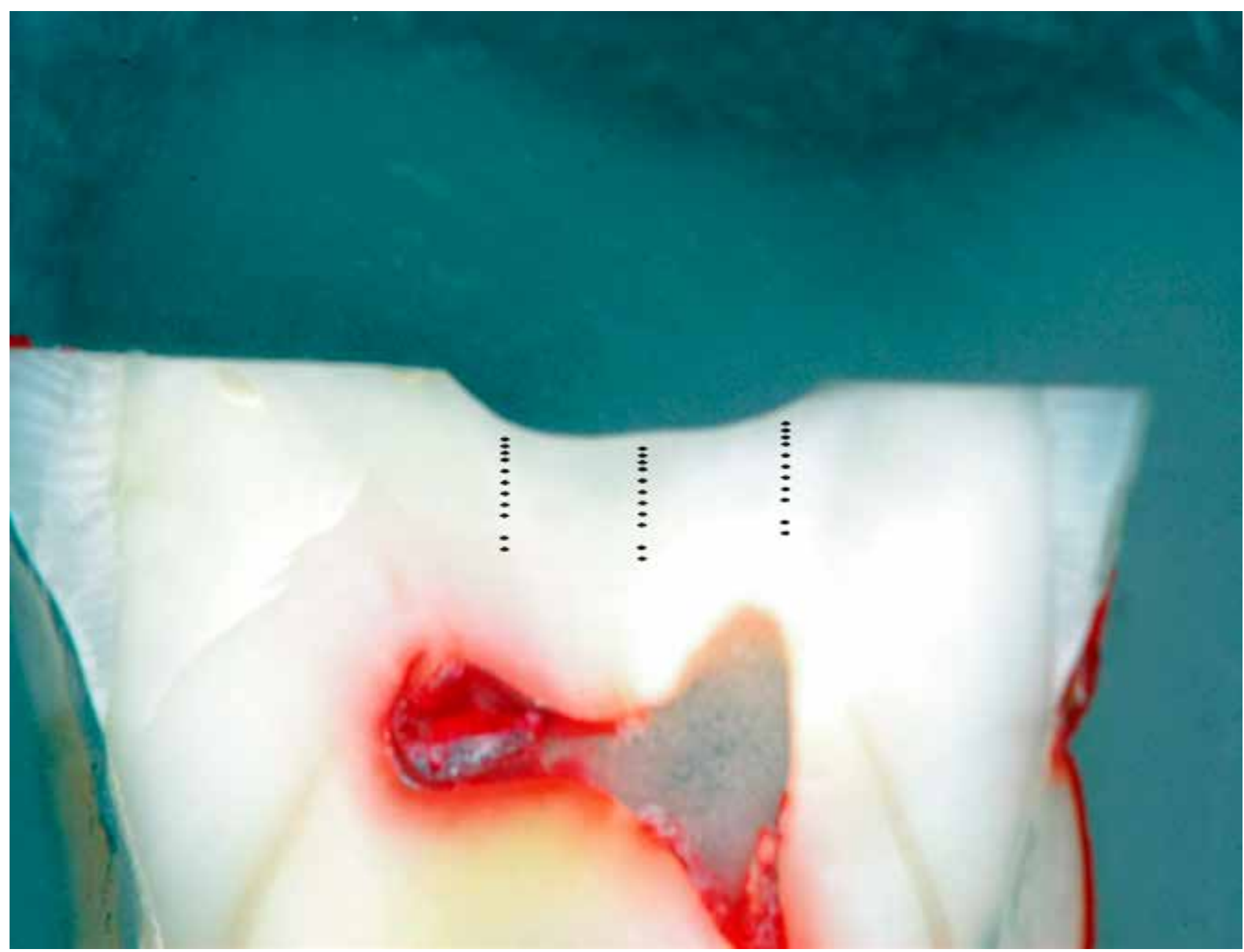


For cavity depth, the means among the excavation methods within mineralized dentin were compared using Kruskal-Wallis One-Way ANOVA on Ranks and the Tukey test $(\alpha=0.05)$, and within demineralized dentin were compared using One-Way ANOVA and the Holm-Sidak method $(\alpha=0.05)$. For each excavation method, the means between dentin types were compared using the t-test. For each mechanical dentin removal method, when normal distribution was assumed after the KolmogorovSmirnov test, the means of microhardness values were compared among all the dentin levels using the One-Way ANOVA and post hoc Holm-Sidak method $(\alpha=0.05)$. In cases where normal distribution failed, the means of microhardness values were compared among all dentin levels using the Kruskal-Wallis One-Way ANOVA on Ranks and the Tukey test ( $\alpha$
$=0.05)$. The same statistical analysis was applied for each dentin level.

\section{RESULTS}

Table 1 shows the cavity depths $(\mu \mathrm{m})$. A significant difference coulb be observed in cavity depths when different excavation methods were used to remove mineralized $(\mathrm{p}<0.001)$ and demineralized dentin $(\mathrm{p}<0.001)$. Cavities were deeper in demineralized dentin than in mineralized dentin for all excavation methods $(\mathrm{p}<0.001)$. The steel bur produced the deepest cavities (mineralized dentin: $55.0 \mu \mathrm{m} \pm 20.68$; demineralized dentin: $102.0 \mu \mathrm{m}$ $\pm 22.51)$. The polymer bur generated the shallowest cavity in demineralized dentin $(41.0 \mu \mathrm{m} \pm 7.38)$ and was unable to remove mineralized dentin.

Table 1 - Mean (SD) of cavity depth $(\mu \mathrm{m})(\mathrm{n}=10)$.

\begin{tabular}{lll}
\hline & Mineralized dentin & Demineralized dentin \\
\hline Steel bur & $55.0(20.68) \mathrm{A} \mathrm{a}$ & $102.0(22.51) \mathrm{B} \mathrm{a}$ \\
Hand instrument & $13.00(8.23) \mathrm{A} \mathrm{b}$ & $59.0(15.95) \mathrm{B} \mathrm{b}$ \\
Polymer bur & $0(0) \mathrm{A} \mathrm{c}$ & $41.0(7.38) \mathrm{B} \mathrm{c}$ \\
\hline
\end{tabular}

In rows, same capital letters indicate no significant difference $(\mathrm{p}<0.05)$; in columns, same small letters indicate no significant difference $(\mathrm{p}<0.05)$.

Table 2 presents the results of microhardness values. No significant difference could be observed among microhardness values when different excavation methods were used to remove mineralized dentin $(\mathrm{p}<0.001)$. The microhardness values of mineralized dentin were similar at all levels $(\mathrm{p}>$ $0.001)$.

Regarding demineralized dentin, when compared to the mineralized dentin hardness values, none of the three removal methods were able to achieve similar microhardness values with the dentin at the base of the excavated cavities $(\mathrm{p}<0.001)$. Demineralized dentin microhardness beneath cavities produced with the steel bur and hand instrument presented similar values $(p=0.441)$. Microhardness values of the dentin beneath the cavities produced by polymer burs were lower than those produced by the other two instruments $(\mathrm{p}<0.001)$, except at 20 , 140,180 , and $200 \mu \mathrm{m}$ levels, where there was no significant difference among the three groups. There was a significant difference between microhardness at $10 \mu \mathrm{m}$ and $200 \mu \mathrm{m}(\mathrm{p}<0.001)$ for the polymer bur group.

\section{DISCUSSION}

Some previous research on caries removal methods used natural lesions in human dentin ${ }^{4,6,16,17-19}$. However, when natural lesions are used, it is difficult to standardize all of the variables that occur among samples $^{20}$. It was also difficult to collect the large number of decayed teeth needed ${ }^{9}$. The use of a $\mathrm{pH}$ cycling method for inducing artificial caries lesions in human teeth is a good and reliable choice for simulating a carious lesion when compared with other methods, since the hardness values obtained with this cycling model are similar to those obtained from natural caries lesions 9 . Moreover, among in vitro protocols, this type of $\mathrm{pH}$-cycling involves the combinations of demineralization and remineralization ${ }^{21}$, as the development of caries lesions represents the imbalance in the cycle of demineralization and remineralization ${ }^{22}$.

Rotatory instruments, such as steel and carbide burs, are the most widely used caries-excavation methods $^{3}$, and are considered the most efficient methods to remove caries in terms of time ${ }^{16}$. However, the use of burs tends to over-excavate dentin as the removal endpoint is based on a subjective visualtactile examination of dental tissues ${ }^{16}$. In this present study, steel burs showed the deepest cavities in both demineralized and mineralized dentin, reflecting a higher level of dentin removal when compared to the other two methods. Therefore, the first hypothesis was rejected. In a clinical situation, it is reported that steel burs promotes the removal of both healthy dentin tissue as well as the caries of infected dentin ${ }^{20}$, and is considered a non-selective method for caries removal.

Selective removal of the demineralized dentin 
Table 2 - Knoop microhardness values at each depth from cavity floor according to different dentin removal methods $(\mathrm{n}=10)$

\begin{tabular}{|c|c|c|c|c|c|c|c|c|c|c|c|c|c|}
\hline & & $10 \mu \mathrm{m}$ & $20 \mu \mathrm{m}$ & $30 \mu \mathrm{m}$ & $40 \mu \mathrm{m}$ & $50 \mu \mathrm{m}$ & $60 \mu \mathrm{m}$ & $80 \mu \mathrm{m}$ & $100 \mu \mathrm{m}$ & $120 \mu \mathrm{m}$ & $140 \mu \mathrm{m}$ & $180 \mu \mathrm{m}$ & $200 \mu \mathrm{m}$ \\
\hline \multirow[t]{2}{*}{$\begin{array}{l}\text { Mineralized } \\
\text { Dentin }\end{array}$} & & $\begin{array}{l}60.6 \\
(0.9) \\
\text { A a }\end{array}$ & $\begin{array}{l}61.2 \\
(0.2) \\
\text { A a }\end{array}$ & $\begin{array}{l}61.7 \\
(2.9) \\
\text { A a }\end{array}$ & $\begin{array}{l}61.8 \\
(3.2) \\
\text { A a }\end{array}$ & $\begin{array}{l}62.9 \\
(1.6) \\
\text { A a }\end{array}$ & $\begin{array}{l}62.7 \\
(1.5) \\
\text { A a }\end{array}$ & $\begin{array}{l}62.3 \\
(1.3) \\
\text { A a }\end{array}$ & $\begin{array}{l}61.8 \\
(2.1) \\
\text { A a }\end{array}$ & $\begin{array}{l}62.6 \\
(2.5) \\
\text { A a }\end{array}$ & $\begin{array}{l}62.2 \\
(2.2) \\
\text { A a }\end{array}$ & $\begin{array}{l}61.6 \\
(2.3) \\
\text { A a }\end{array}$ & $\begin{array}{l}62.3 \\
(1.8) \\
\mathrm{A} \mathrm{a}\end{array}$ \\
\hline & Steel bur & $\begin{array}{l}46.9 \\
(7.5) \\
\text { A b }\end{array}$ & $\begin{array}{l}46.1 \\
(8.5) \\
\text { A b }\end{array}$ & $\begin{array}{l}47.6 \\
(7.2) \\
\text { A b }\end{array}$ & $\begin{array}{l}49.6 \\
(11.0) \\
\text { A b }\end{array}$ & $\begin{array}{l}49.9 \\
(8.6) \\
\text { A b }\end{array}$ & $\begin{array}{l}51.9 \\
(8.8) \\
\text { A b }\end{array}$ & $\begin{array}{l}50.8 \\
(7.6) \\
\text { A b }\end{array}$ & $\begin{array}{l}49.5 \\
(7.3) \\
\text { A b }\end{array}$ & $\begin{array}{l}49.9 \\
(8.8) \\
\text { A b }\end{array}$ & $\begin{array}{l}52.4 \\
(10.4) \\
\text { A b }\end{array}$ & $\begin{array}{l}50.6 \\
(9.9) \\
\text { A b }\end{array}$ & $\begin{array}{l}50.8 \\
(10.8) \\
\text { A b }\end{array}$ \\
\hline $\begin{array}{l}\text { Demineral- } \\
\text { ized dentin }\end{array}$ & $\begin{array}{l}\text { Hand ins- } \\
\text { trument }\end{array}$ & $\begin{array}{l}49.9 \\
(5.8) \\
\text { A b }\end{array}$ & $\begin{array}{l}44.8 \\
(12.8) \\
\text { A b }\end{array}$ & $\begin{array}{l}45.6 \\
(13.9) \\
\text { A b }\end{array}$ & $\begin{array}{l}46.1 \\
(15.0) \\
\text { A b }\end{array}$ & $\begin{array}{l}46.3 \\
(15.8) \\
\text { A b }\end{array}$ & $\begin{array}{l}47.4 \\
(14.5) \\
\text { A b }\end{array}$ & $\begin{array}{l}47.2 \\
(14.7) \\
\text { A b }\end{array}$ & $\begin{array}{l}47.2 \\
(15.0) \\
\text { A b }\end{array}$ & $\begin{array}{l}48.9 \\
(14.5) \\
\text { A b }\end{array}$ & $\begin{array}{l}49.8 \\
(14.1) \\
\text { A b }\end{array}$ & $\begin{array}{l}48.2 \\
(11.6) \\
\text { A b }\end{array}$ & $\begin{array}{l}48.4 \\
(14.9) \\
\text { A b }\end{array}$ \\
\hline & $\begin{array}{l}\text { Polymer } \\
\text { bur }\end{array}$ & $\begin{array}{l}31.1 \\
(8.4) \\
\text { A c }\end{array}$ & $\begin{array}{l}31.8 \\
(7.9) \\
\text { A,B b }\end{array}$ & $\begin{array}{l}32.5 \\
(7.3) \\
\text { A,B c }\end{array}$ & $\begin{array}{l}34.0 \\
(6.6) \\
\text { A,B c }\end{array}$ & $\begin{array}{l}35.7 \\
(7.4) \\
\text { A,B c }\end{array}$ & $\begin{array}{l}36.1 \\
(7.9) \\
\text { A,B c }\end{array}$ & $\begin{array}{l}37.2 \\
(7.7) \\
\text { A,B c }\end{array}$ & $\begin{array}{l}39.1 \\
(8.1) \\
\text { A,B c }\end{array}$ & $\begin{array}{l}39.8 \\
(8.0) \\
\text { A,B c }\end{array}$ & $\begin{array}{l}41.0 \\
(8.5) \\
\text { A,B b }\end{array}$ & $\begin{array}{l}42.6 \\
(8.4) \\
\text { A,B b }\end{array}$ & $\begin{array}{l}43.8 \\
(8.0) \\
\text { B b }\end{array}$ \\
\hline
\end{tabular}

In rows, same capital letters indicate no significant difference $(\mathrm{p}<0.05)$; in columns, same small letters indicate no significant difference $(\mathrm{p}<0.05)$.

infected by caries is not easily achieved with a steel bur or hand excavator ${ }^{18}$. It is suggested that manual caries removal with a hand instrument is the most reliable method of the two to avoid this excessive removal of tissue ${ }^{20}$. When comparing a steel bur and hand excavator, it is reported that a hand instrument removes softened tissue with more sensitive tactile feedback than a bur ${ }^{14}$. The current data shows that the hand instrument removed less demineralized dentin than did steel burs, but it still removed more demineralized tissue than did the polymer burs. The hand instrument was able to remove mineralized dentin, while the polymer bur was not able to remove this type of substrate. Therefore, it seems that, among the three excavations methods, polymer burs are more self-limiting than the other methods regarding the removal of dentin. Polymer burs seem to be able to accomplish their purpose of being less destructive ${ }^{6,7,16}$.

Microhardness is used to indirectly assess the mineral content of the dentin. This study encountered means of Knoop hardness value that ranged from 58.81 to $65.22 \mathrm{kgf} / \mathrm{mm}^{2}$ for mineralized dentin, which is in accordance with values found in other studies that ranged from 35 to $70 \mathrm{kgf} / \mathrm{mm}^{215,24,25}$. Although the intention was not to extrapolate the hardness values as a way to evaluate the actual mineral content of dentin, they were used to compare the groups. The Knoop hardness values of mineralized dentin at each level were used as a reference, ensuring the reliability of the measurement of hardness in demineralized dentin.

The Knoop hardness of caries-infected dentin ranges from $5.5-25^{24} \mathrm{kgf} / \mathrm{mm}^{2}$, whereas those of caries-affected dentin ranges from $10-50^{24} \mathrm{kgf} /$ $\mathrm{mm}^{2}$. According to some authors ${ }^{9}$, the $\mathrm{pH}$-cycling model provides similar hardness values to naturally caries-affected dentin. However, this method has some limitations. The duration of demineralization and remineralization periods is unknown, and it is impossible to precisely control dentin demineralization depth. Furthermore, this method does not employ saliva and biofilm. Thus it does not simulate a dentin caries lesion with an evident infected layer, but does simulate a lesion prior to caries removal ${ }^{9}$. It is possible that the limited action of all tested excavation methods is due to the type of demineralized dentin produced by the $\mathrm{pH}$-model, which is more similar to real cariesaffected dentin.

When taking microhardness data into consideration, none of the excavation methods was able to completely remove artificially demineralized dentin. The hardness values of the remaining dentin underneath the cavities were significantly lower than the values of mineralized dentin. This result shows that any method could remove all of the demineralized dentin, but none was able to remove all of the mineralized tissue. The steel bur and hand instrument showed similar demineralized dentin removal effectiveness when considering that the Knoop values of dentin below the cavities prepared with both instruments were significantly lower (ranges $46.1 \pm 8.5$ to $52.4 \pm 10.4$ and $44.8 \pm 12.8$ to $49.9 \pm$ 5.8 , respectively) than those values of mineralized dentin. Therefore, the second hypothesis was partially accepted. Additionally, when the real level of each indentation is considered (Table 2), the steel bur presented microhardness values that were similar to the hand instrument, but at deeper levels.

When observing the Knoop values of dentin below the cavities produced by a polymer bur, it is suggested that demineralized dentin still remains, as these values ranged from $31.1 \pm 8.4$ to $43.8 \pm 8.0$. At all measurement levels, Knoop values were significantly lower than those of the steel bur and hand instrument.

As the demineralized dentin produced by the $\mathrm{pH}$-cycling method is similar to caries-affected dentin, it could be suggested that the steel bur was 
the most aggressive method. It appears that this method does not correspond to the current concepts of minimal invasive dentistry. The current authors also hypothesize that the $\mathrm{pH}$-cycling model produced an entire superficial demineralized dentin as well as a partial demineralized dentin towards the pulp. The steel bur and hand instrument could remove the entire demineralized dentin but could only partially remove demineralized dentin.

On the other hand, the authors of this study suggest that the polymer bur could only selectively remove part of the demineralized dentin. The polymer bur is harder than infected dentin but softer than normal dentin ${ }^{7}$. Polymer burs present slightly lower microhardness values $(50 \mathrm{KHN})$ than sound dentin, but is greater than that attributed to carious dentin ${ }^{6}$. When the bur touches sound or caries-affected dentin, it becomes dull and produces a vibration, making further cutting impossible ${ }^{23}$. According to the current data, the removal of demineralized dentin is within the range of polymer bur action.

\section{CONCLUSION}

Within the limitations of this present study, it is possible to conclude that the effectiveness of the removal of demineralized dentin varied among the three contemporary dentin excavation methods. The polymer bur obtained the highest preservation of demineralized dentin after excavation with regards to cavity depth and hardness of the remaining dentin. The steel bur and hand instrument showed similar demineralized dentin removal effectiveness regarding the hardness of the remaining dentin tissue, but produced different cavity depths. Further studies are necessary to investigate the correlation between the effectiveness of caries removal methods on artificial demineralized dentin produced by distinct methods as well as on natural carious dentin.

\section{RESUMO}

Objetivo: Avaliar a efetividade de diferentes métodos mecânicos de remoção de dentina desmineralizada. Materiais e Métodos: Terceiros molares humanos, hígidos, foram preparados de forma que as superfícies oclusais planas de dentina fossem expostas e seccionadas longitudinalmente, no sentido vestíbulo-lingual. Uma secção de cada dente foi submetida a um modelo de ciclagem de $\mathrm{pH}$ e outra secção permaneceu sem nenhum tratamento. As secções dos dentes foram unidas e a dentina foi removida por um único operador, pelo uso de broca de aço, cureta de dentina ou broca de polímero. As secções dos dentes foram então separadas e fotografias digitais foram realizadas. A profundidade das cavidades preparadas, assim como as mensurações de microdureza, foram aferidas e analisadas por testes estatísticos One Way ANOVA Kruskal-Wallis em Ranks, teste de Tukey, enquanto as dentinas desmineralizadas foram comparadas por One-Way ANOVA e Holm-Sidak $(\mathrm{p}<0.05)$. Resultados: A broca de aço produziu as cavidades mais profundas, tanto em dentina mineralizada como desmineralizada. A broca de polímero produziu as cavidades mais rasas em dentina desmineralizada. As medidas de microdureza da superfície mais profunda dos preparos em dentina desmineralizada indicaram que a broca de aço e a cureta de dentina apresentaram valores similares, enquanto que os provenientes das cavidades preparadas com broca de polímero tiveram valores numéricos menores. Conclusão: A efetividade na remoção de dentina desmineralizada variou entre os três métodos utilizados. A broca de polímero foi o método mais conservador. Já a broca de aço e a cureta de dentina tiveram efetividade similar de remoção da dentina desmineralizada, de acordo com os valores de microdureza da dentina remanescente, embora tenham produzido preparos de profundidades diferentes.

Descritores: Desmineralização do dente. Preparo da cavidade dentária. Testes de dureza.

\section{REFERENCES}

1. Fusayama T, Okuse K, Hosoda H. Relationship between hardness, discoloration, and microbial invasion in carious dentin J Dent Res. 1966; 45:1033-46.

2. Murdoch-Kinch CA, McLean ME. Minimally invasive dentistry. J Am Dent Assoc. 2003; 134:87-95.

3. Bussadori SK, Castro LC, Galvão AC. Papain gel: a new chemo-mechanical caries removal agent. J Clin Pediatr Dent. 2005; 30:115-9.

4. Neves AA, Coutinho E, De Munck J, Van Meerbeek B. Caries-removal effectiveness and minimal-invasiveness potential of cariesexcavation techniques: a micro-CT investigation. J Dent. 2011a; 39:154-62.

5. Mount GJ. Minimal intervention dentistry: rationale of cavity design. Oper Dent. 2003; 28:92-9.

6. Silva NR, Carvalho RM, Pegoraro LF, Tay FR, Thompson VP. Evaluation of a self-limiting concept in dentinal caries removal. J Dent Res. 2006; 85:282-6.

7. Boston DW. New device for selective dentin caries removal. Quintessence Int. 2003; 34:67885.

8. Allen KL, Salgado, TL, Janal MN, Thompson VP. Removing carious dentin using polymer instrument without anesthesia versus a carbide bur with anesthesia. J Am Dent Assoc. 2005; 136:643-51. 
9. Marquezan M, Corrêa FN, Sanabe ME, Rodrigues Filho LE, Hebling J, Guedes-Pinto AC, et al. Artificial methods of dentine caries induction: a hardness and morphological comparative study. Arch Oral Biol. 2009; 54:1111-7.

10. Ten Cate JM. In vitro studies of the effects of fluoride on de- and remineralization. J Dent Res. 1990; 69:634-6.

11. Ten Cate JM, Duijsters PP. Alternating demineralization and remineralization of artificial enamel lesions. Caries Res. 1982; 16:201-10.

12. White DJ. The application of in vitro models to research on demineralization and remineralization of the teeth. Adv Dent Res. 1995; 9:175-93.

13. Argenta RM, Tabchoury CP, Cury JA. A modified $\mathrm{pH}$ cycling model to evaluate fluoride effect on enamel demineralization. Pesqui Odontol Bras. 2003; 17:241-6.

14. Banerjee $\mathrm{A}$, Kidd $\mathrm{EA}$, Watson $\mathrm{TF}$. In vitro validation of carious dentin removed using different excavation criteria. Am J Dent. 2003; 16:228-30.

15. Craig RG, Gehring PE, Peyton FA. Relation of structure to the microhardness of human dentin. J Dent Res. 1959; 38:624-30.

16. Celiberti P, Francescut P, Lussi A. Performance of four dentine excavation methods in deciduous teeth. Caries Res. 2006; 40:117-23.

17. Zhang X, Tu R, Yin W, Zhou X, Li X, Hu D. Micro-computerized tomography assessment of fluorescence aided caries excavation (FACE) techniques. Aust Dent J. 2013; 58:461-7.

18. Banerjee A, Kellow S, Mannocci F, Cook RJ, Watson TF. An in vitro evaluation of microtensile bond strengths of two adhesive bonding agents to residual dentine after caries removal using three excavation techniques. J Dent. 2010a; 38:480-9.

19. Cajazeira MRR, Santos MEO. Ultrastructural analysis of the dentin surface of primary molars submitted to different methods udes for removal of carious tissue. Pesqui Bras Odontopediatria Clin Integr. 2007; 7:265-9.

20. Banerjee A, Sherriff M, Kidd EA, Watson TF. A confocal microscopic study relating the autofluorescence of carious dentine to its microhardness. Br Dent J. 1999; 187:206-10.

21. Buzalaf MA, Hannas AR, Magalhães AC, Rios D, Honório HM, Delbem AC. pH-cycling models for in vitro evaluation of the efficacy of fluoridated dentifrices for caries control: strengths and limitations. J Appl Oral Sci. 2010; 18:316-34.

22. Mount, GJ. A new paradigm for operative dentistry. Aust Dent J. 2007; 52:264-70.

23. Neves AA, Coutinho E, Cardoso MV, Lambrechts $P$, Van Meerbeek B. Current concepts and techniques for caries excavation and adhesion to residual dentin. J Adhes Dent. 2011b; 13:7-22.

24. Banerjee A, Cook R, Kellow S, Shah K, Festy F, Sherriff $\mathrm{M}$, et al. A confocal micro-endoscopic investigation of the relationship between the microhardness of carious dentine and its autofluorescence. Eur J Oral Sci. 2010b; 118:759.

25. Fuentes V, Toledano M, Osorio R, Carvalho RM. Microhardness of superficial and deep sound human dentin. J Biomed Mater Res A. 2003; 66:850-3. 